\title{
KARST SINKHOLES AS FOCI OF BIODIVERSITY IN THE HOOSIER NATIONAL FOREST
}

\author{
Julian J. Lewis ${ }^{1, C}$, Marc A. Milne², Charles D. R. Stephen³, and Daniel C. Dourson ${ }^{4}$
}

\begin{abstract}
Sinkholes are a well-known, but poorly studied, aspect of karst environments. In 2015, the Hoosier National Forest in southern Indiana, USA, commissioned a study of sinkhole habitats to assess their ecological role. The ecosystems of 26 sinkholes were evaluated to determine if sinkhole floor biological communities and species richness were a function of the surrounding plant community. Each sinkhole was sampled four times for five target groups of invertebrates at intervals of approximately three months, for a total of 104 visits. The sampling resulted in finding 140 taxa, including 31 land snails, 14 millipedes, 3 terrestrial isopods, 83 spiders and 9 pseudoscorpions. Of exceptional note were at least 12 new state records and a probable new species of pseudoscorpion. Several of these species appear to be endemic to sinkhole habitats. A link was confirmed between species richness and the surrounding plant community, specifically that the highest biodiversity was found in sinkholes surrounded by native deciduous forest, followed by native glades. Sinkholes in fields from which deciduous forest had been removed possessed markedly decreased species diversity, as did non-native plantings of pines. Sinkhole habitats had a significantly higher species richness than adjacent non-sinkhole control sites. Moreover, the arthropod communities that were found in each sinkhole within each plant community type were different from each other and the surrounding non-sinkhole areas. These data suggest that sinkholes are more than just depressions in epigean landscapes, but possess unique invertebrate communities linked to the surrounding plant community.
\end{abstract}

\section{INTRODUCTION}

Between 2015 and 2017 a project was initiated by the Hoosier National Forest (HNF) to evaluate the biological communities of sinkholes and their relationship with the surrounding forest environment. This study was motivated in part by a desire to better manage the forest through an improved understanding of the effects of modifying forest plant communities on sensitive karst sinkhole ecosystems.

The HNF spans approximately $800 \mathrm{~km}^{2}$ and is spread across nine counties in southcentral Indiana (Fig. 1). The geologic setting (Powell, 1961; Frushour, 2012; Lewis, 2012; Lewis and Lewis, 2012b) is comprised of the sandstone-capped ridges of the Crawford Upland, with limestone-floored valleys where caves and springs are common. In ridges penetrated by these caves, sinkholes tend to occur in places where the sandstone cap has collapsed into underlying limestone caves. Frequently this resulted in sandstone-walled sinks where little if any limestone is available for calciphilic animals, such as terrestrial snails. In contrast, the eastern edge of the HNF lies in the Mitchell Sinkhole Plain, a region characterized by copious numbers of sinkholes formed entirely in limestone.

Extensive literature exists on forest (e.g., Homoya et al., 1985) and cave ecology (e.g., Culver and Pipan, 2009), but little has been written on that of the sinkhole ecotone that connects these surface and subterranean environments. As a frame of reference from which to start in the evaluation of the sinkhole fauna, the HNF cave fauna has been well-characterized after two decades of bioinventory projects (Lewis, 1998a, 1998b, 2011; Lewis et al., 2002, 2004; Lewis and Lewis, 2008, 2009, 2012a). Beyond that, the literature concerning sinkholes mostly addresses three topics: (1) engineering nuisances that swallow homes and complicate construction projects; (2) the wetlands and associated communities that are created when sinkholes become plugged (Scott, 1910; White, 1930); and (3) fossil remains (primarily Tertiary in age), mostly animals that fell into pit-like sinkholes and were unable to escape (Farlow et al., 2001).

The goals of this project were to relate the fauna of sinkholes with four kinds of surrounding plant communities and to test whether native plant communities harbored greater sinkhole fauna species richness. The two hypotheses for the project were: (1) that sinkhole floor fauna communities were a function of the surrounding plant community type: and (2) species richness was a function of the presence of native deciduous forest in which the communities had evolved since the end of the last Pleistocene glacial advance.

\section{METHODS}

The methods for the project were chosen to facilitate identification and characterization of the chosen sinkholes, to provide data necessary to quantify the amount of leaf litter present in each sink, the extent of the invertebrate com-

\footnotetext{
${ }^{1}$ Lewis and Associates LLC, Cave, Karst and Groundwater Biological Consulting, 17903 State Road 60, Borden, IN 47106

${ }^{2}$ Department of Biology, University of Indianapolis, $1400 \mathrm{E}$. Hanna Avenue, Indianapolis, IN 46227

${ }^{3}$ Department of Biological Sciences, Auburn University, 101 Rouse Life Sciences, Auburn, AL 36849

${ }^{4}$ Dourson Environmental Consulting, 1128 Gritter Ridge Road, Stanton, KY 40380

c Corresponding Author: lewisbioconsult@gmail.com
} 


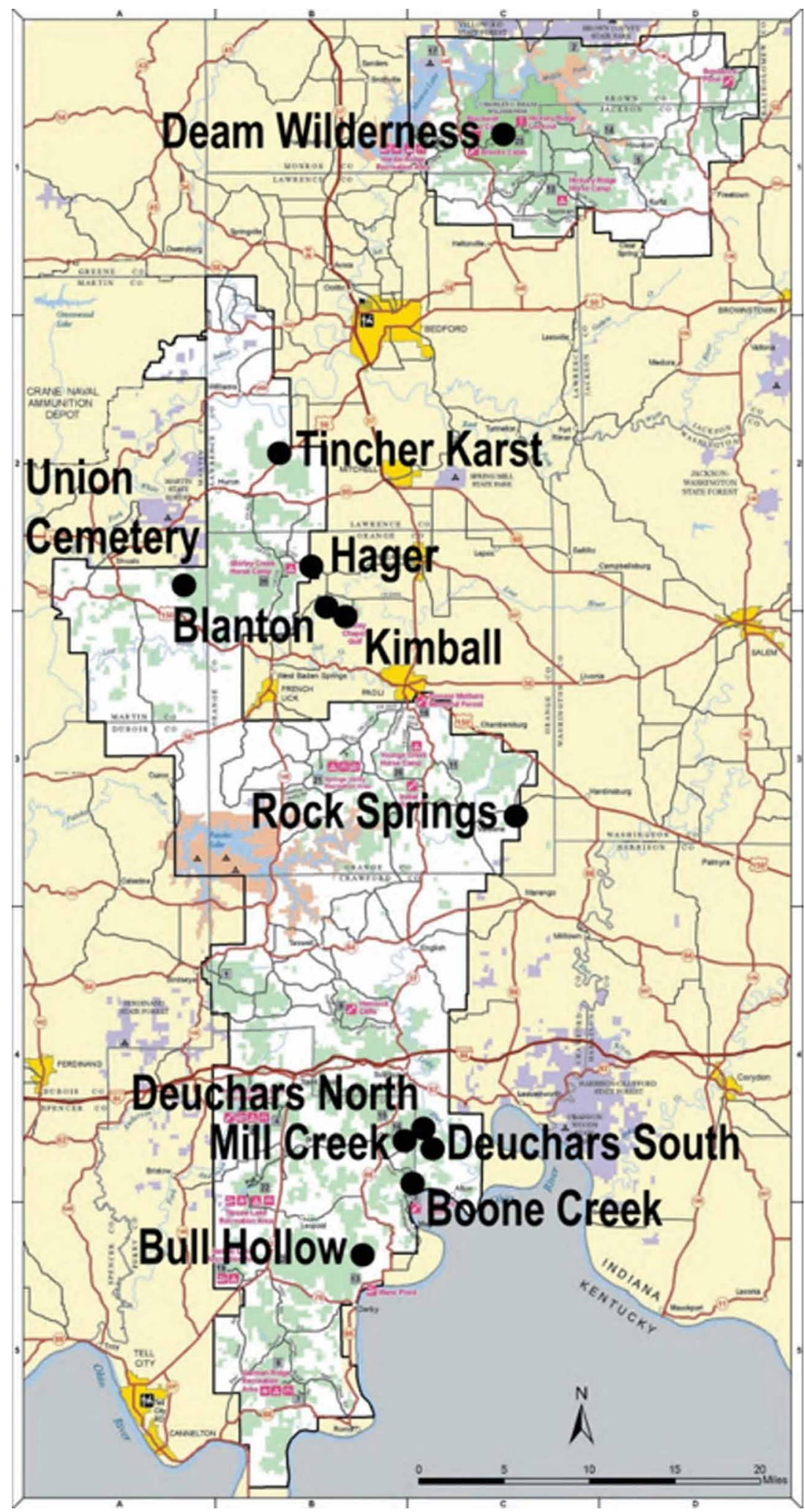

Figure 1. Map of the purchase boundary of the Hoosier National Forest in southern Indiana, with tracts labelled in which sinkholes were investigated. munity, and the identification of some of the species present. Particular constraints were time, limited funding, and personnel with taxonomic expertise. Some of the methods expressed here were relevant for aspects of the project that were tangential to the faunistic portion of the project and will be further discussed in a future paper focusing on the environment of HNF sinkholes.

Twenty-five sinkholes were evaluated between September 2015 and June 2016. The Forest Service suggested that sinkholes with cave entrances be eliminated from consideration to ascertain a clear distinction between this project and several others that focused on caves. The Forest Service made no stipulations as to which sinkholes were selected, although it was requested that a variety of shapes and sizes be chosen, including some that were only subtly different from the surrounding landscape. Control sites were selected in adjacent non-sinkhole habitats for comparison with deciduous forest, glade grasslands, and pine plantings (at Tincher Special Karst, Bull Hollow, and Deuchars North, respectively).

Each sink and control site were visited four times, at approximately three-month intervals such that there was sampling coverage during all seasons. Additionally, a single large sink was studied with the same protocol between July 2016 and May 2107. A total of 104 visits were conducted. Site names were chosen based on Forest Service designation, if available (e.g., Kimball Tract, Blanton Tract), or a nearby landmark (e.g., Union Cemetery). Location coordinates were obtained with a Garman Oregon 450 GPS. Dimensions (length, width, and depth) were measured with a laser measuring device or a tape measure (Table 1). Extensive data concerning other environmental parameters (e.g., temperature, humidity, soil $\mathrm{pH}$ ) were gathered and will be discussed in a separate paper.

Sinkholes surrounded by four plant communities were studied: (1) deciduous forest comprised of native tree species that in the HNF are predominantly oaks (Quercus spp.), sugar maple (Acer saccharum), and hickories (Carya spp.) (Woodall et al., 2007); (2) glades - natural openings in deciduous forests in rocky areas with shallow soil, with sparse trees and meadows inhabited by warm-season grasses and other prairie plants; (3) pine plantations - row plantings of pines (Pinus spp.) that are otherwise rare or absent in Indiana forests, comprising monocultures that are sporadically invaded by maple trees that contribute some deciduous forest leaves 


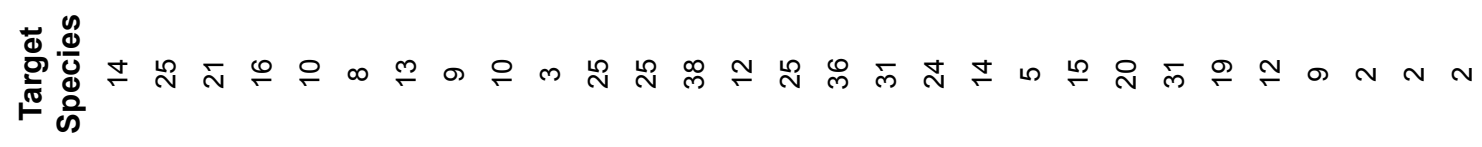

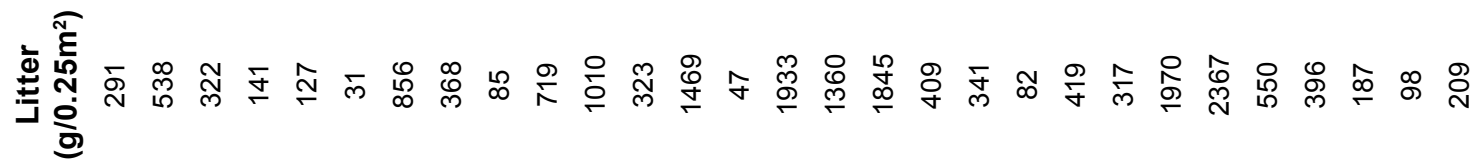

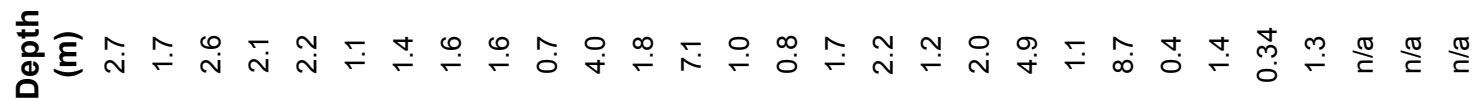

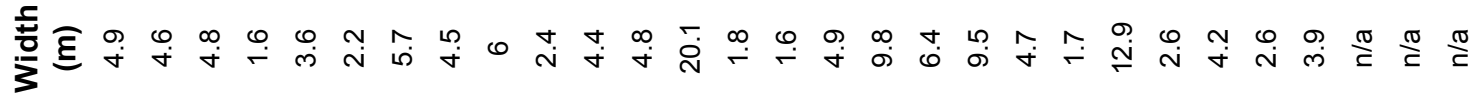

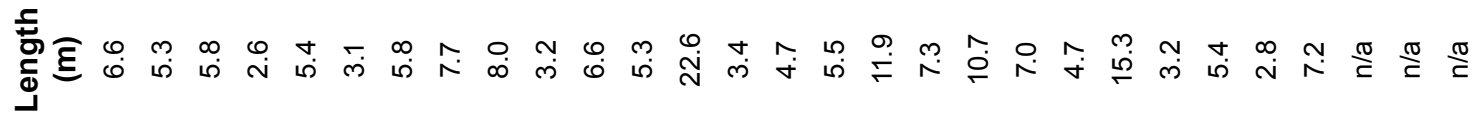

車

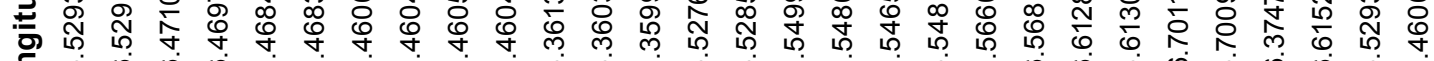

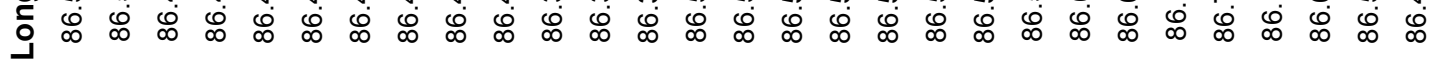

응

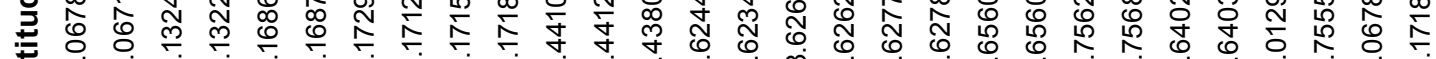
J

$\stackrel{0}{\mp} \stackrel{\circ}{\underline{1}}$

过

里 $\subseteq$

응 일

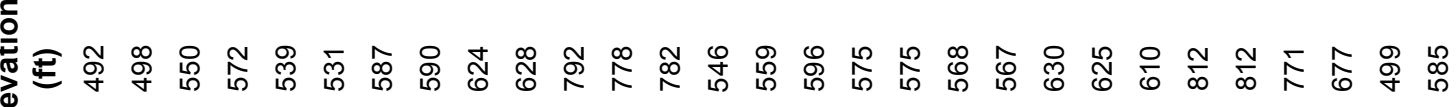

兵离

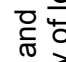

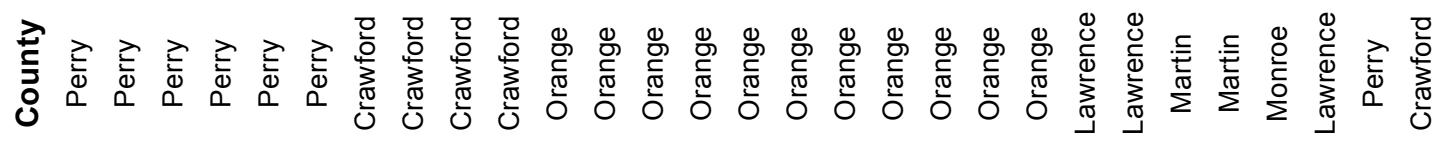

을 $\frac{0}{0}$

든

站 $\frac{\infty}{7}$

은

के

$\stackrel{+\frac{1}{0}}{\stackrel{0}{0}}$

ธิ

峁 $\widehat{\bar{N}} \widehat{\widetilde{N}}$

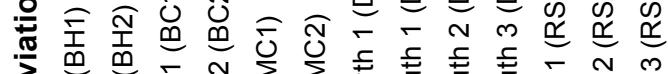

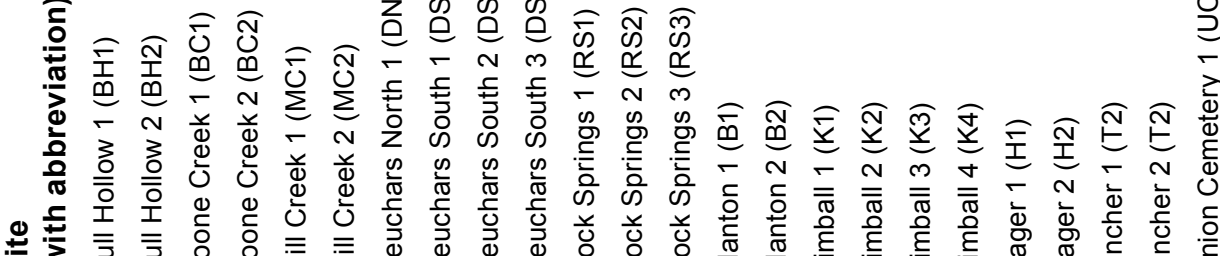

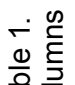

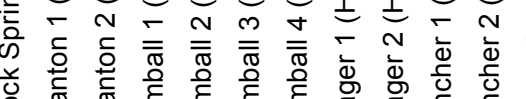

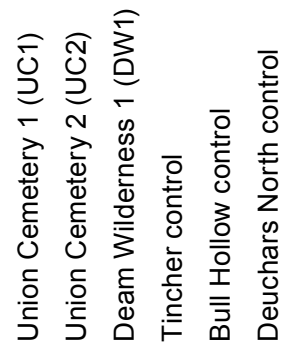


to the forest leaf litter; and (4) fields - former crop land or pasture abandoned from agricultural use and dominated by weedy plants, like goldenrod (Solidago spp.) and ironweed (Vernonia spp.). The plant community in which each sinkhole occurred was characterized by field identifications at each site into one of the four types.

During the initial visit of each sink a $0.25 \mathrm{~m}^{2}$ quadrat was placed in the central drain area of the sink floor. The depth of the leaf litter from the surface to the top of the underlying soil was measured. All organic material present was removed from the quadrat and weighed. The litter sample was reduced by sifting through a $1.0 \mathrm{~cm}^{2}$ mesh screen, bagged for transport, and placed in a Berlese funnel at the laboratory to extract invertebrates. During subsequent visits to the sinkholes, qualitative collecting was done by thoroughly searching a transect $0.3 \mathrm{~m}$ wide and extending from the center of the sinkhole to the rim. A different transect was set for each collection due to the disruptive nature

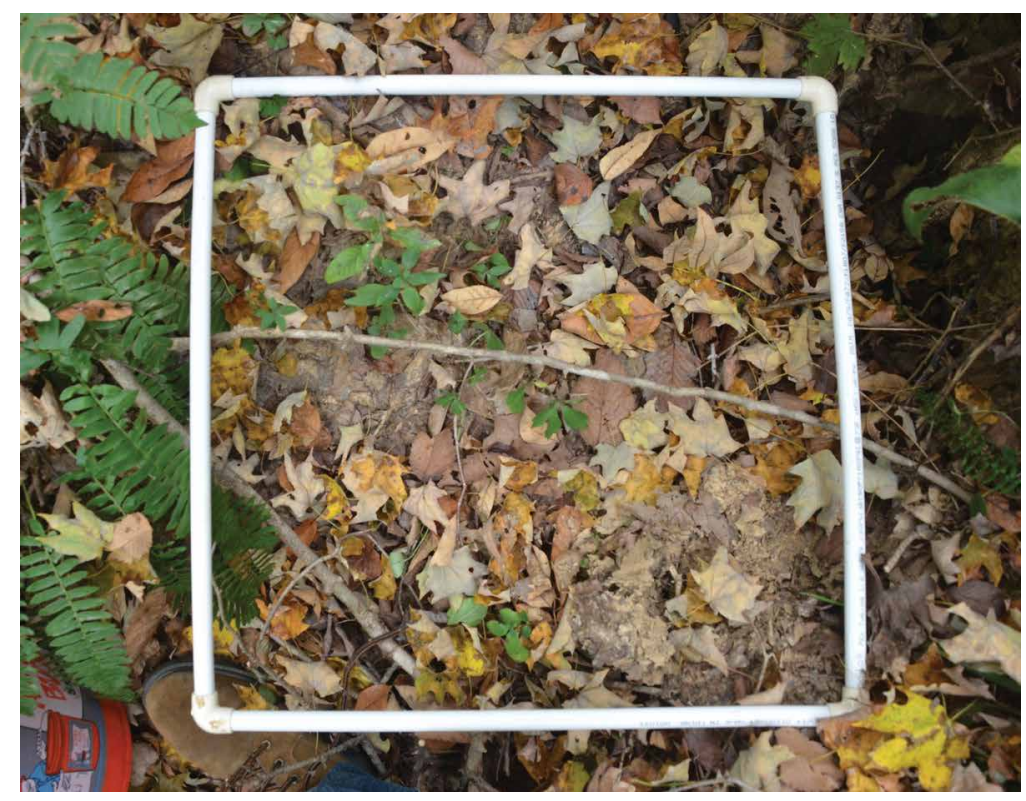

Figure 2. Example of a typical quadrat placement in Bull Hollow sinkhole 1. of sampling. Leaf litter from the transect was screened onto a white surface and target invertebrates placed into $70 \%$ ethanol for transport to the laboratory.

Five invertebrate groups were chosen as targets for collection and identification based on the availability of taxonomic expertise. The target groups and specialists were: terrestrial isopods and millipedes (J. Lewis), spiders (M. Milne), pseudoscorpions (C. Stephen) and terrestrial snails (D. Dourson). Specimens were shipped to the institutions of the authors responsible for identification. Vouchers for pseudoscorpions are deposited at the Auburn University Museum of Natural History; terrestrial isopods are deposited in the collection of the Smithsonian Institution. Other vouchers remain in the collections of the authors.

To determine if there was a significant difference in species richness between the controls and the sinkhole habitats, a $t$-test was completed. To compare species richness among habitat types, an ANOVA was employed. Additionally, a Tukey HSD test was done to determine which specific habitats were significantly different than others. To compare the taxonomic makeup of the communities (composed of all target species) at various sites in different habitat types, including controls, a non-metric multidimensional scaling analysis (NMDS) was completed in R (R Development Core Team, 2019) version 3.4.3 using the associated vegan package (Oksanen et al., 2019). Data were log normal transformed prior to the NMDS. Between-habitat comparisons were analyzed in $\mathrm{R}$ with a pairwise multilevel comparison analysis, using the pairwise adonis function in vegan. Plots were created in R with the package ggplot2 (Wickham et al., 2019).

\section{TRACT DESCRIPTIONS}

Locations of the 26 sinkholes are shown in Figure 1, with coordinates and dimensions in Table 1. The sinkholes ranged from $2.6 \mathrm{~m}$ to $22.6 \mathrm{~m}$ long in the greatest dimension (mean 6.8), $1.6 \mathrm{~m}$ to $20.1 \mathrm{~m}$ wide (mean 5.2) and $0.3 \mathrm{~m}$ to $8.7 \mathrm{~m}$ deep (mean 2.2). Brief descriptions follow for the sinkholes chosen among 12 Forest Service tracts in the HNF.

\section{Bull Hollow Tract}

A remote area accessed by all-terrain vehicle, located on the ridge above the confluence of Bull Hollow and Oil Creek, about $3 \mathrm{~km}$ north of the confluence with the Ohio River. An area of extensive glades, sink 1 is steep-walled in a glade with sparse leaf litter on bare clay with an open drain (Fig. 3). The native grass, River Oats (Chasmanthium latifolium), occurred on the margins of the sink. Sink 2 was in sparse deciduous forest on the edge of the forest-glade interface, with more leaf litter present in the floor than observed in sink 1.

\section{Boone Creek Tract}

This tract is characterized by extensive glades and occurs on the north side of a ridge one km northwest of the Ohio River. Sinkhole plant communities were characterized by sparse forest and River Oats (C. latifolium) on the sinkhole margins. Sink 1 had a slightly over-hanging wall with limestone exposed on the floor. Litter was sparse with slabs of rock scattered on the floor under which was a drain hole that always had an air temperature approximating local cave temperatures (ca. $12.5^{\circ} \mathrm{C}$ ). Sink 2 was small, steep-walled, bordered by limestone and leading into an open drain. At this sinkhole little organic litter was present; the floor and walls were mostly bare soil and limestone. 


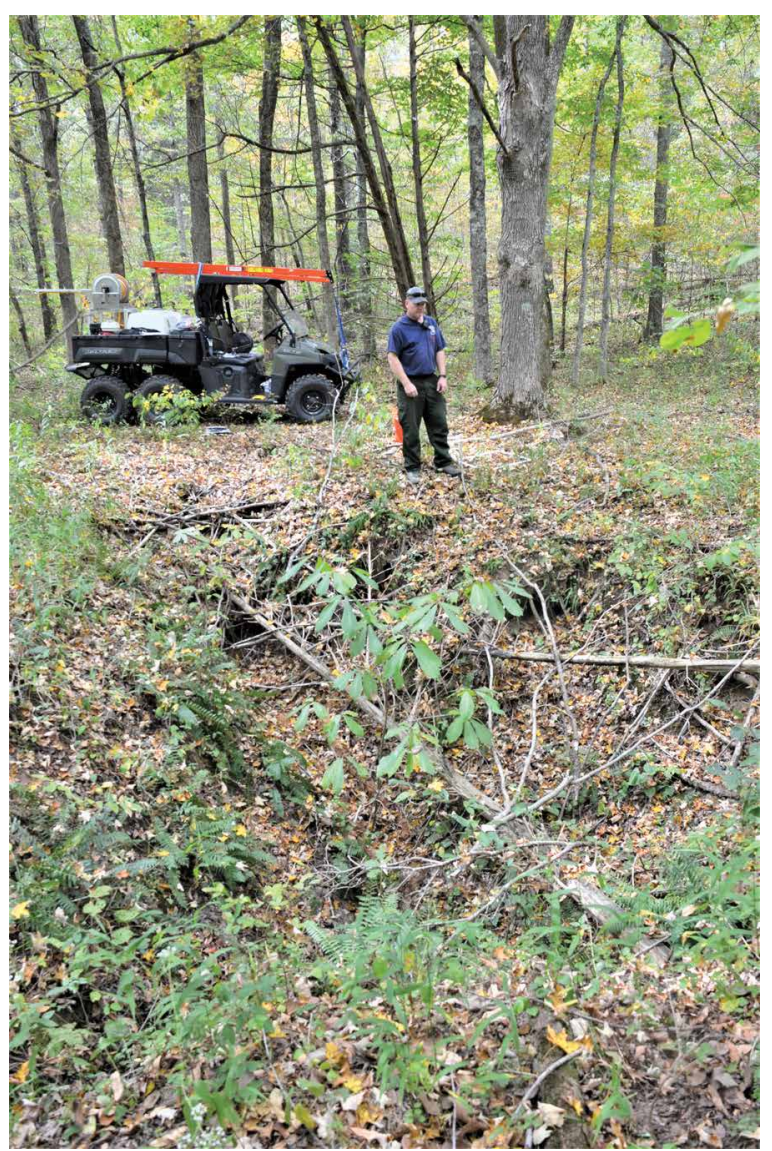

Figure 3. Bull Hollow sinkhole 1.

\section{Mill Creek Tract}

This site is an old field, currently being converted by HNF personnel to native grasses. Trash and other remnants of old buildings indicate the presence of a former homesite. Sink 1 had vertical sandstone walls that overhung the floor slightly on one side. This sink was judged as significantly disturbed, with the floor containing trash, road gravel, and wood ashes. A mostly dead, exotic Tree-ofheaven (Ailanthus altissima) overhung one end of the sink. A floor drain had air temperature consistently near local cave temperature. The adjacent sink 2 was shallower and formed completely in soil with no visible rock.

\section{Deuchars North and South Tracts}

Just northeast of the Mill Creek Tract, the four sinks in the two tracts designated Deuchars North and South are in mature monoculture pine plantings on opposite sides of a county road. The North Deuchars sink 1 was an open bowl-shaped depression with a thick layer of forest litter, primarily pine needles with some maple leaves. Three sinks were selected in South Deuchars. Sinks 1 and 3 were floored with pine mulch (bark and needles). Sink 2 was filled to the rim with trash, including quantities of broken glass and rusty metal that may have been a source of chemical pollution negatively affecting the sinkhole fauna.

\section{Rock Springs Tract}

This tract is named after the Rock Springs Church located about $1 \mathrm{~km}$ to the northwest; no springs are present on this upland area that drains into the Patoka River. Three sinks were chosen for evaluation, two studied the first year and the third singled out for attention the following year because of its large size. All were in established deciduous forest and occurred just above the sandstone and limestone contact, with limestone exposed in sinks 1 and 3 . Sink 1 was steep-walled with an active drain. Sink 2 was bowl-shaped with no apparent drain. Sink 3 was steep-walled and a hand line was used for entry due to its depth of over 7 meters. Sink 3 had an overhanging rock shelter with exposed limestone under the sandstone, and a hole that did not function as a drain but breathed air that was consistently near cave temperature. The overhang in sink 3 was the only site inhabited by the cave cricket (Ceuthophilus stygius) found in dense clusters and the Cave Salamander (Eurycea lucifuga).

\section{Blanton Tract}

This tract is on the western margin of the Mitchell Sinkhole Plain and contains two entrances to the 35+ km Lost River Cave System. Both of the sinkholes selected in this tract had limestone exposed in the walls. Sink 1 occurred in

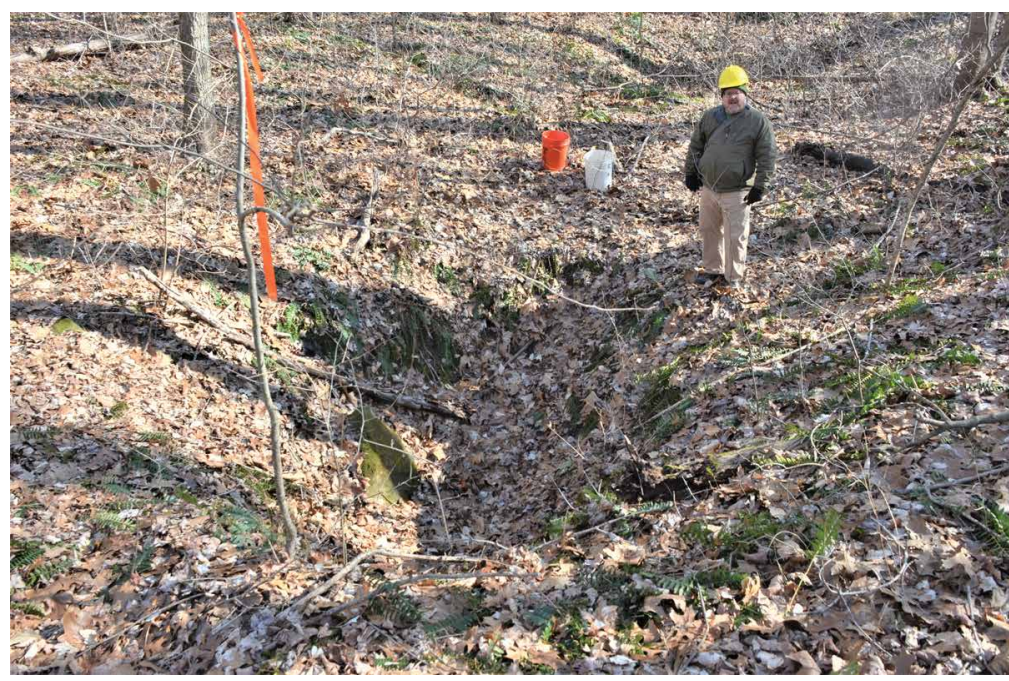

Figure 4. Kimball Tract sinkhole 1. an old field and was narrow and elongate. Sink 2 was in deciduous forest, formed along an enlarged joint and appeared like a rectangular stone box. An abandoned wooden shed was a short distance away and one end of the sink was covered by a large bale of fence wire, obvious evidence of past human disturbance.

\section{Kimball Tract}

Prior to purchase by the HNF, this tract had been held by a company maintaining it for a timber harvest. The tract forms a peninsula surrounded by the dry bed of Lost River, comprised of dense sinkhole formation under a moderately mature deciduous forest that was not recently harvested. The sinkholes occur at the sandstone and limestone contact. Sink 1 was a somewhat elongate bowl-shaped depression (Fig. 4). Sinks 2 and 4 
were similar, but broader and more open. Sink 3 was broad and shallow, with many chunks of limestone on the floor that were suspected to have been the result of human placement there. An old stone-lined cistern was a few meters away from the sink.

\section{Hager Tract}

The two sinks chosen in this tract were in different habitats. Sink 1 was in a large, flat, lowland field overgrown with weeds that would have been almost impenetrable without the trail bush-hogged by Forest Service personnel to allow access during this project. The sink had one scraggly tree growing above the steep wall of the sink above what looked like a mostly buried metal tank. This sink was the only one that changed markedly over the course of the year it was visited, with an open drain that breathed out water vapor that created a dense hoarfrost on the wall during mid-winter. In the spring the wall above the drain collapsed and completely sealed the drain with loose soil. Sink 2 was near the top of a hill adjacent to a wide swath of mowed gas pipeline right-of-way. The sink was rectangular with sandstone walls.

\section{Tincher Karst Special Area}

This area is one of the most rugged parts of the HNF. Two sinks were selected on the karst valley floor between two large sandstone ridges. Sink 1 was the deepest of any selected and the second largest overall. A spring emerging from the ridge side some distance from the sink created a waterfall that plummeted down the vertical limestone wall of the sink and disappeared in breakdown. The floor of sink 1 was consistently wet and much of the leaf litter disappeared into the drain, leaving bare clay substrate. Sink 2, in contrast, was a broad, shallow depression that trapped leaves. Despite its small size, sink 2 was the third most biodiverse sink studied.

\section{Union Cemetery Tract}

Two sinks were selected in this remote area that lies near the top of a ridge. The first sinkhole was a bowl-shaped depression lacking any drain. A small spring occurred at the base of the small slope beyond the rim of the sink. Sink 2 was the smallest of any evaluated, a shallow depression only a third of a meter deep that trapped little leaf litter.

\section{Deam Wilderness}

This karst area is comprised of a narrow sliver of limestone thrust to the surface adjacent to the Mt. Carmel Fault Zone. Only one sink was located that did not have an open vertical fissure or pit. This sink, in a mature pine planting, was an elongate bowl-shaped depression that sloped toward a drain hole. The sparse litter on the floor was a combination of pine needles and maple leaves.

\section{RESULTS AND DISCUSSION}

A total of 140 taxa from the target groups of fauna were found in the 26 sinkholes (Tables 2-6). These included 31 land snails, 14 millipedes, 3 terrestrial isopods, 83 spiders, and 9 pseudoscorpions (Tables 2-6). Of the 140 taxa, 113 were found in 5 or fewer sites, and another 17 in 10 or fewer sinks, accounting for about $93 \%$ of the target fauna collected. Of the species that made recurrent use of sinkholes, eight taxa occurred in 11-15 sites, and only the spiders Leucauge venusta and Pirata spp. occurred in more than 15 sinks. These are common epigean spiders of the Midwest with no particular affinity to sinkholes that has been reported (Sierwald et al., 2005). Leucauge venusta was found in 18 sinks, where its webs were spun on taller plants during the summer and autumn months. In contrast, Pirata spp., including three specific taxa as well as seemingly ubiquitous juveniles, were found in moist litter in 24 sinks.

Spiders were the most diverse faunal group (Tables 4-6). Eleven species of spiders were new state records (Milne et al., 2017) at the time of their discovery in HNF sinks: Cicurina itasca, Ceratinops latus, Ceratinopsidis formosa, Mermessus maculatus, Walckenaeria communis, Gladicosa pulchra, Phrurolithus singulus, Scotinella redempta, Pisaurina dubia, Neon nelli, and Robertus frontatus.

Several rare species were encountered in certain sinkholes. The pseudoscorpion Kleptochthonius griseomanus was found only in Kimball sink 1 (Fig. 5). It was previously known only from the entrance zones of four caves in Crawford and Perry counties, Indiana (Muchmore, 2000; Lewis and Lewis, 2012a), with one or two pseudoscorpions found in each cave. It was thus surprising to find over 30 specimens in a single litter sample taken from Kimball sink 1, which suggests that the preferred habitat of this species may be sinkhole floors and not caves. At each sampling event the sinkhole floor, rim, and mid-wall areas were sampled, but K._griseomanus was only collected from the floor. The finding of Chitrella sp. (family Syarinidae) in Rock Springs sink 1 is significant. This specimen likely represents an undescribed species and is a range expansion for the genus, which in eastern North America was previously only known from one epigean locality in Tennessee and caves in Tennessee, Virginia, and West Virginia (Malcolm and Chamberlin, 1960; Muchmore, 1963, 1973).

Among the millipedes, Conotyla bollmani was reported by Hoffman and Lewis (1997) from caves in the northern half of the Mitchell Plain and Crawford Upland. Shear (1971) reported an unspecified record outside of a cave. In caves, the species is troglomorphic, with reduced eyes and depigmented. Conotyla bollmani was found in 15 HNF sinkholes, 
Table 2. Terrestrial snails occurring in HNF sinkholes.

\begin{tabular}{|c|c|c|c|c|c|c|c|c|c|c|c|c|c|c|c|c|c|c|c|c|c|c|c|c|c|c|c|c|c|c|}
\hline Site & 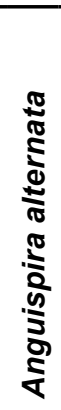 & 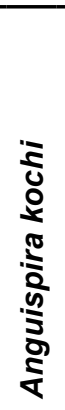 & 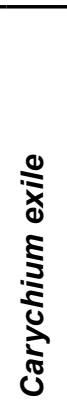 & 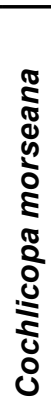 & 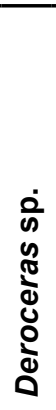 & 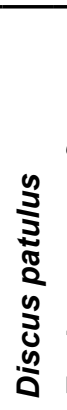 & 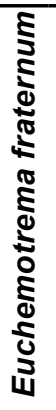 & 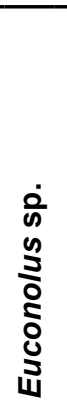 & 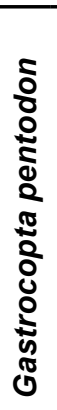 & 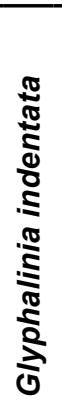 & 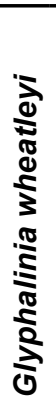 & 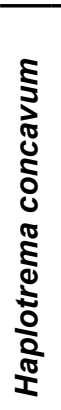 & 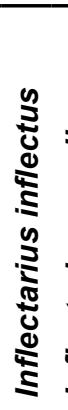 & 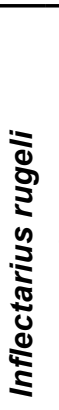 &  & 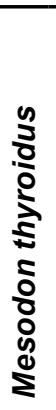 & 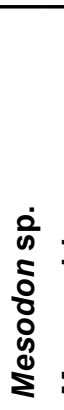 & 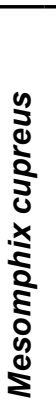 & 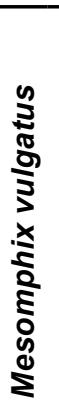 & 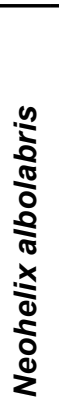 & 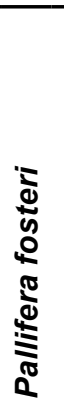 & & 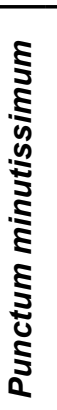 & 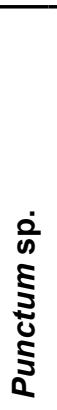 & 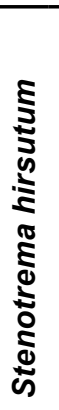 & 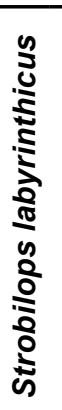 & 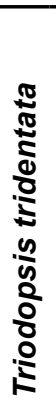 & 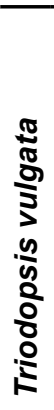 & 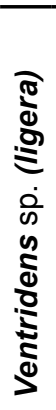 & 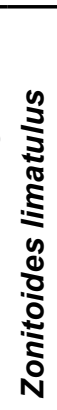 \\
\hline Bull Hollow sink 1 & & & & & & & & & & & & $x$ & & & & & $\mathrm{X}$ & & & & & & & & & & & & & \\
\hline Bull Hollow sink 2 & & & & & & & & & & & & $x$ & & & & & & & & & & & $X$ & & & & & & & \\
\hline Boone Creek sink 1 & & & $x$ & & & & & & & & & $x$ & & & & & & & & & & & & & & & $x$ & $x$ & & \\
\hline Boone Creek sink 2 & & & $x$ & & & & & & & & & $x$ & & & & & & & & & & $x$ & & & & & $x$ & $x$ & & \\
\hline Mill Creek sink 1 & & & & & & & & & & & & & & & & & & & & & & & & & & & & & & \\
\hline Mill Creek sink 2 & & & & & & & & & & & & & & & & & & & & & & & & & & & & & & \\
\hline Deuchars North sink 1 & & & & & & & & & & & & & & & & & & & & & & & & & & $\mathrm{x}$ & & & & \\
\hline Deuchars South sink 1 & & & & & & & & & & & & & & & & & & & & & & & & & & & & & & \\
\hline Deuchars South sink 2 & & & & & & & & & & & & & & & & & & & & & & & & & & & & & & \\
\hline Deuchars South sink 3 & & & $\mathrm{X}$ & & & & & & & & & & & & & & & & & & & & & & & & & & & \\
\hline Rock Springs sink 1 & & & & & & & & & & & & & & & & & & & & $\mathrm{x}$ & & & & $x$ & & & & & & \\
\hline Rock Springs sink 2 & & & & & & & & & & & $x$ & $x$ & & & & & & & & $x$ & & & & & & & $\mathrm{X}$ & & & \\
\hline Rock Springs sink 3 & $x$ & & $x$ & & & & & & & $\mathrm{x}$ & & $\mathrm{x}$ & & & & & & & & & & & & & & & & & & \\
\hline Blanton sink 1 & & & & & & & & & & & & $\mathrm{X}$ & & & & & & & & & & & & & & & & $x$ & & \\
\hline Blanton sink 2 & $x$ & & $x$ & & & $\mathrm{X}$ & & $x>$ & $\mathrm{x}$ & $x$ & & & & $\mathrm{X}$ & & & & & & & & & $x$ & & & $\times$ & $\mathrm{x}$ & & & \\
\hline Kimball sink 1 & & & & & & & & & & & $\mathrm{X}$ & $x$ & & & & & & $x$ & & & & & & & & & $\mathrm{x}$ & & & \\
\hline Kimball sink 2 & & $x$ & & & & & & & & $x$ & & $x>$ & $x$ & & & & & & & & & & & & & & $\mathrm{x}$ & & & \\
\hline Kimball sink 3 & $x$ & $x y$ & $x$ & & & & & & & & & $\mathrm{X}$ & & & & $\mathrm{X}$ & & & $\mathrm{X}$ & & $\mathrm{x}$ & & & & $x$ & & $x$ & & & \\
\hline Kimball sink 4 & $x$ & & & & & & & & & & & & & & & & & & & & & & & & & & $x$ & & $x$ & \\
\hline Hager sink 1 & & & & & & & & & & & & & & & $x$ & & & & & & & & & & & & & & & \\
\hline Hager sink 2 & & & & & $x$ & & & & & & & & & & & & & & & & & & & & & & & & & \\
\hline Tincher sink 1 & & & $x$ & & & & $x$ & & & & $x$ & & $\mathrm{x}$ & & & & & & & & & & & & & & $x$ & & & \\
\hline Tincher sink 2 & & & $x$ & $x$ & & & & & $x$ & & $x$ & & $x$ & & & $x$ & & & & & & $x$ & & & & & & & & $x$ \\
\hline Union Cemetery sink 1 & & & & & & & $x$ & & & & & $x$ & $x$ & & & & & & & $x$ & & & & & & & & & & \\
\hline Union Cemetery sink 2 & & & $x$ & & & & & & & & & & & & & & & & & $x$ & & & & & & & & & & \\
\hline $\begin{array}{l}\text { Deam Wilderness } \\
\text { sink } 1\end{array}$ & & & & & & & & & & & & & $x$ & & & & & $x$ & & & & & & & & & & & & \\
\hline \multicolumn{31}{|l|}{ Bull Hollow control } \\
\hline \multicolumn{31}{|l|}{ Tincher control } \\
\hline $\begin{array}{l}\text { Deuchars North } \\
\text { control }\end{array}$ & & & & & & & & & & & & & & & & & & & & & & & & & & & & & & \\
\hline
\end{tabular}

although adult males were encountered only from sinks in the Rock Springs tract, where they were darkly pigmented with normal eyes. The finding of the millipede Cleidogona unita is a new record for Indiana and represents a range expansion for the species. This millipede was reported by Shear (1971) from habitats along the sandstone escarpment in southern Illinois and Mammoth Cave National Park, Kentucky. It was found in sinks in the Bull Hollow, Deuchars and Tincher tracts, where it co-occurred with Conotyla bollmani.

Terrestrial snails were relatively scarce given the presence of limestone in karst topography. Without question, calcium carbonate is an essential mineral to land snails for regulation of bodily processes, reproduction, and most importantly, shell-building. Land snails obtain calcium in several ways including consuming soil particles from calcareous substrates, eating decaying leaf matter, almost certainly by ingesting Physarales slime molds which precipitate amor- 


\begin{tabular}{|c|c|c|c|c|c|c|c|c|c|c|c|c|c|c|c|c|}
\hline Site & $\begin{array}{l}\dot{0} \\
0 \\
\delta \\
\frac{0}{0} \\
\tilde{0} \\
\frac{0}{\alpha}\end{array}$ & 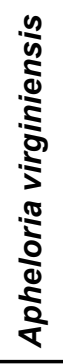 & $\begin{array}{l}\frac{\partial}{0} \\
\frac{\pi}{\pi} \\
\tilde{\delta} \\
\text { हึ } \\
0\end{array}$ & 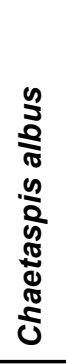 & 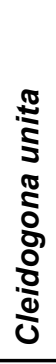 & 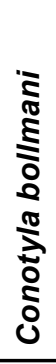 & 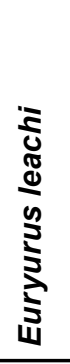 & 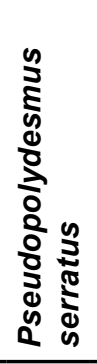 & 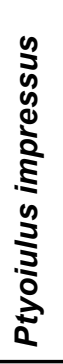 & 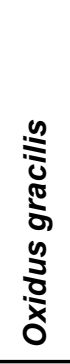 & 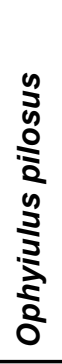 & 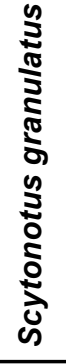 & 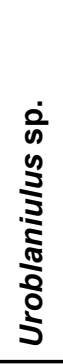 & 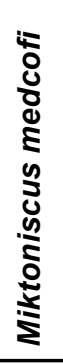 & 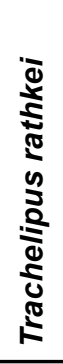 & 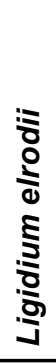 \\
\hline Bull Hollow sink 1 & & & $x$ & & & $x$ & & & & & & & & & & \\
\hline Bull Hollow sink 2 & $x$ & & & & $\mathrm{x}$ & $x$ & & & & & & & $\mathrm{x}$ & & $\mathrm{x}$ & $x$ \\
\hline Boone Creek sink 1 & & & & & & $x$ & & $\mathrm{x}$ & & & & & & & $x$ & $x$ \\
\hline Boone Creek sink 2 & & & & & & $x$ & & $\mathrm{x}$ & & & & $\mathrm{x}$ & & $x$ & $x$ & $x$ \\
\hline Mill Creek sink 1 & & & & & & & & $\mathrm{x}$ & & & & & & & $x$ & $x$ \\
\hline Mill Creek sink 2 & & & & & & $\mathrm{x}$ & & & & & & & & & & $x$ \\
\hline Deuchars North sink 1 & & & & & $\mathrm{x}$ & $\mathrm{x}$ & & & & & & & & & $x$ & \\
\hline Deuchars South sink 1 & & & & & & & & & & & & & & & & $x$ \\
\hline Deuchars South sink 2 & & & & & & & $\mathrm{x}$ & $\mathrm{x}$ & & & & $x$ & & & & \\
\hline Deuchars South sink 3 & & & & & & & & $\mathrm{x}$ & & & & & & & & \\
\hline Rock Springs sink 1 & & & & & & $\mathrm{x}$ & & $\mathrm{x}$ & & $\mathrm{x}$ & $\mathrm{x}$ & $\mathrm{x}$ & & & & \\
\hline Rock Springs sink 2 & & $\mathrm{x}$ & & & & $\mathrm{x}$ & $\mathrm{x}$ & & & $\mathrm{x}$ & $\mathrm{x}$ & & & & & \\
\hline Rock Springs sink 3 & & & & $\mathrm{X}$ & & $\mathrm{x}$ & $\mathrm{x}$ & $\mathrm{x}$ & & $\mathrm{x}$ & $\mathrm{x}$ & $\mathrm{x}$ & & & & $\mathrm{x}$ \\
\hline Blanton sink 1 & & & & & & & & & & $\mathrm{x}$ & $\mathrm{x}$ & & & & $x$ & \\
\hline Blanton sink 2 & $\mathrm{x}$ & & & & & & $\mathrm{x}$ & $\mathrm{x}$ & & $\mathrm{x}$ & $\mathrm{x}$ & & & & $x$ & \\
\hline Kimball sink 1 & $\mathrm{x}$ & & & $\mathrm{X}$ & & $\mathrm{x}$ & & $\mathrm{x}$ & $\mathrm{x}$ & $\mathrm{x}$ & $x$ & & & $\mathrm{x}$ & & \\
\hline Kimball sink 2 & & & & & & $\mathrm{x}$ & & & & $\mathrm{x}$ & $\mathrm{x}$ & & $x$ & & & \\
\hline Kimball sink 3 & & & & & & & & $\mathrm{x}$ & & $\mathrm{x}$ & $\mathrm{x}$ & & & & $x$ & $\mathrm{x}$ \\
\hline Kimball sink 4 & & & & & & $\mathrm{x}$ & & & & $\mathrm{x}$ & $\mathrm{x}$ & & & & & \\
\hline Hager sink 1 & & & & & & & & & & & $\mathrm{x}$ & & & & & \\
\hline Hager sink 2 & & & & & & $\mathrm{x}$ & & $\mathrm{x}$ & & $\mathrm{x}$ & $\mathrm{x}$ & $\mathrm{x}$ & & & $x$ & $\mathrm{x}$ \\
\hline Tincher sink 1 & & & & & $\mathrm{x}$ & $\mathrm{x}$ & & $\mathrm{x}$ & & & $\mathrm{x}$ & & & & & $\mathrm{x}$ \\
\hline Tincher sink 2 & $\mathrm{x}$ & & & & & $\mathrm{x}$ & $\mathrm{x}$ & $\mathrm{x}$ & & $\mathrm{x}$ & $x$ & & & & & \\
\hline Union Cemetery sink 1 & & & & & & & & & & & $x$ & $\mathrm{x}$ & & & & $\mathrm{x}$ \\
\hline \multicolumn{17}{|l|}{ Union Cemetery sink 2} \\
\hline Deam Wilderness sink 1 & & & & & & & & $\mathrm{x}$ & & & $x$ & & & & & \\
\hline \multicolumn{17}{|l|}{ Bull Hollow control } \\
\hline Tincher control & & & & & & & & & & & & & & & & \\
\hline Deuchars North control & & & & & & & & & & & & & & & & \\
\hline
\end{tabular}

phous calcium carbonate, and gleaning calcium from the shells and bones of deceased animals. Terrestrial gastropods living around carbonate cliffs can exhibit large and diverse populations but show significant declines in abundance in as little as $50 \mathrm{~m}$ from a calcareous source or limestone cliff (Dourson et al., 2013).

The most unusual terrestrial snail encountered was originally described by Pilsbry (1948) as the ecological morph Anguispira kochi form aperta, from an unspecified habitat in Spring Mill State Park. The form was synonymized with $A$. kochi by Hubricht (1985). Specimens with the morphology of this ecological morph were found in Kimball Tract sinks 2 and 3. Although the location at Spring Mill was unspecified, like the Kimball Tract, the entire state park lies in the Mitchell Sinkhole Plain.

The most common land snail encountered during the study was the carnivorous Haplotrema concavum, documented at 11 sites, followed by Triodopsis tridentata, and Carychium exile: both species were found at 9 sites. All three 
Table 4. Spiders occurring in HNF sinkholes.

\begin{tabular}{|c|c|c|c|c|c|c|c|c|c|c|c|c|c|c|c|c|c|c|c|c|c|c|c|c|c|c|}
\hline Site & 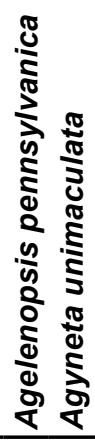 & 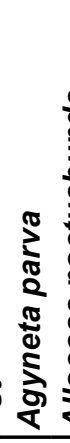 & 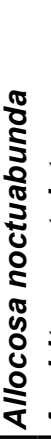 & 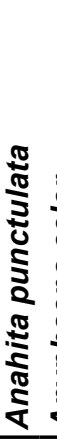 & 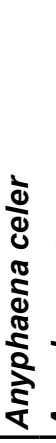 & \begin{tabular}{l} 
\\
\multirow{2}{*}{}
\end{tabular} & 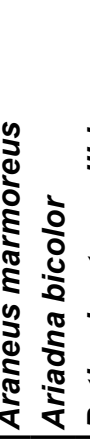 & 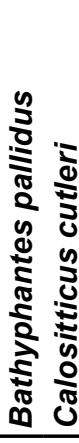 & 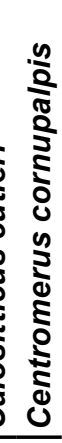 & 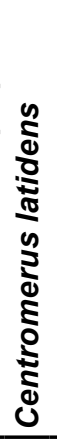 & 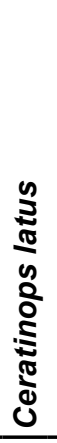 & 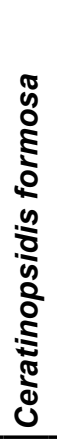 & 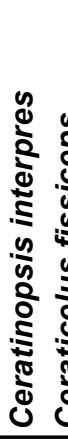 & 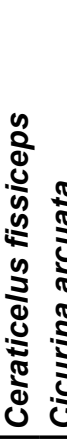 & 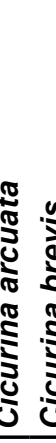 & 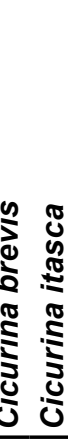 & $\begin{array}{l}\frac{0}{0} \\
\frac{0}{5} \\
\frac{0}{0} \\
0\end{array}$ & 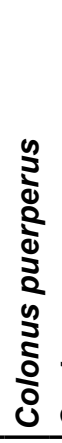 & 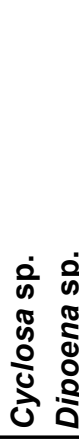 & 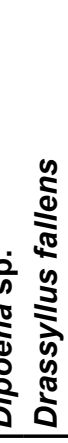 & 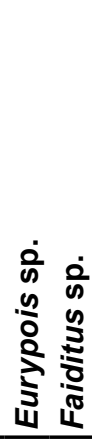 & 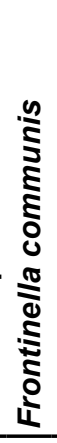 & 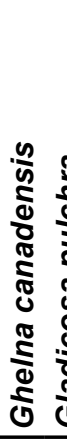 & 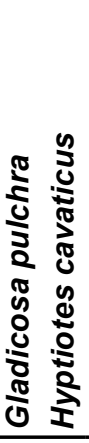 & 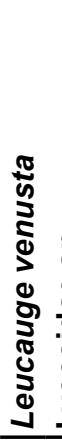 & 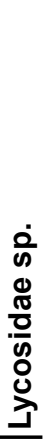 \\
\hline Bull Hollow sink 1 & & & & & & & & & & & & & & & & & $x$ & & & & $x$ & & & & $x$ & \\
\hline Bull Hollow sink 2 & & & & $\mathrm{X}$ & & & & & & $\mathrm{X}$ & & $\mathrm{X}$ & & & & & & & & & & & & & $x$ & \\
\hline Boone Creek sink 1 & & & & $x$ & & $x$ & & & & $\mathrm{X}$ & & & & & & & & & & & & & $x$ & & $x$ & \\
\hline Boone Creek sink 2 & & $x$ & & & & & & & & & & & & & & & & & & & & & & & $\mathrm{X}$ & \\
\hline Mill Creek sink 1 & & & & & & & & $x$ & $x$ & & & & & & $x$ & & & & & & & & & & & \\
\hline Mill Creek sink 2 & & & & & & & & $x$ & & & & & & & & & & & $x$ & & & & & & & \\
\hline Deuchars North sink 1 & & & & $x$ & & & & & & & & & & & & & $x$ & & & & & $x$ & & $x$ & $\mathrm{X}$ & \\
\hline Deuchars South sink 1 & & & & & & & & $\mathrm{x}$ & & & & & & & & & & & & & & & & & $x$ & \\
\hline Deuchars South sink 2 & & & & $x$ & & & & & & & & & & & $x$ & & & & & & & & & & $x$ & \\
\hline Deuchars South sink 3 & & & & & & & & & & & & & & & & & & & & & & & & & & \\
\hline Rock Springs sink 1 & & & & $x$ & & & & & & $\mathrm{X}$ & & & & $x \times$ & $x$ & & $x$ & & & & & & & & $x$ & \\
\hline Rock Springs sink 2 & & & & & & & & $x$ & & $\mathrm{X}$ & & & & & & & $x$ & $\mathrm{X}$ & & & & & & & $x$ & \\
\hline Rock Springs sink 3 & $x$ & & & & & & & $x$ & $x$ & & $\mathrm{X}$ & & & & $x \quad x$ & $x$ & $x$ & & & & & & & $x$ & $x$ & \\
\hline Blanton sink 1 & & & & & & $x$ & & $x$ & & & & & & & & & & $\mathrm{X}$ & & & & & & & & \\
\hline Blanton sink 2 & & & & & & $\mathrm{X}$ & & $x$ & $x$ & & & & & & & & & & & & $x$ & & & & $x$ & \\
\hline Kimball sink 1 & $x$ & $x$ & & & & & & & & $\mathrm{X}$ & & & & & & & $x$ & & & & & $x$ & & & $x$ & \\
\hline Kimball sink 2 & & & & & & & $x$ & & & & & & & & & & & & $x$ & $x$ & & & & & $x$ & \\
\hline Kimball sink 3 & & & & & & & & & & $x$ & & & & & & & & & & & & & & & $x$ & \\
\hline Kimball sink 4 & & & & & & & & & & & & & & & $x$ & & & & & & & & & & $x$ & \\
\hline Hager sink 1 & & & & & & & & $x$ & & & & & & & & & & & & & & & & & & \\
\hline Hager sink 2 & & & & & & & & $x$ & $x$ & & & & & & & & & & & & $x$ & & & & & \\
\hline Tincher sink 1 & & & & & & & & & $x$ & & & & & & & & & & & & & & & & $x$ & \\
\hline Tincher sink 2 & & & $x$ & $\mathrm{X}$ & & $\mathrm{X}$ & & & & & & & & & & $x$ & & & $\mathrm{X}$ & $x \quad x$ & & & & & $x$ & \\
\hline Union Cemetery sink 1 & & & & $x>$ & $\mathrm{X}$ & & & & $x$ & & & & $\mathrm{X}$ & & & & & & $x$ & $x$ & & & & & & \\
\hline Union Cemetery sink 2 & & & & & & & & & & $\mathrm{X}$ & & & & & & & & & & & & & & & $x$ & \\
\hline $\begin{array}{l}\text { Deam Wilderness } \\
\text { sink } 1\end{array}$ & & & & & & & & & & & & & & & $x$ & & & & & & & & & & & \\
\hline \multicolumn{27}{|l|}{ Bull Hollow control } \\
\hline Tincher control & & $x$ & & & & & $\mathrm{x}$ & & & & & & & & & & & & & & & & & & & \\
\hline Deuchars North control & & & & & & & & & & & & & & & X & & & & & & & & & & & $x$ \\
\hline
\end{tabular}

species can be found in both calcareous and acidic environments. Of the 31 species documented in the study area, $87 \%$ are found in both substrates.

The highest number of target species was found in sinkholes within native deciduous forest, followed by glades, then pine plantings and fields, and the non-sinkhole control areas (Fig. 7). We infer species richness to be a function of the presence of organic litter, which accumulates in sinkholes surrounded by forest, but is almost absent in the field habitats. Statistical correlation of quadrat litter weight versus site target species was skewed by the presence of dense mats of pine needles in sinks surrounded by pines that tended to be more mulch-like and inhospitable the heavier the layer became. Some sinks in deciduous forest, e.g., Union Cemetery Sink 1, also had the litter weight skewed by the presence of a chunk of dense, heavy wood occurring in the quadrat. 
Sinkhole habitats had a significantly higher species richness than control sites $\left(t_{7}=3.122, p<0.05\right.$; Fig. 8). Species richness differed significantly among habitats $(F=9.125, p<0.0005$; Fig. 9). Specifically, deciduous forests were significantly more species-rich than fields $(p<0.005)$ and pine habitats $(p<0.005)$. The community of target species varied significantly by habitat $(F=33.24, p<0.0001$; Fig. 10). Specifically, the community of target species within the control habitats was significantly different from within the deciduous forest $(p<0.01)$, fields $(p<0.01)$, and pine habitats $(p<$ $0.05)$. Moreover, the community of target species within the deciduous forest habitat was significantly different from within the field $(p<0.01)$ and the pine habitats $(p<0.01)$. All other comparisons between habitats were not significantly different in the pairwise multilevel comparison analysis.

The relationship of sinkhole dimensions to biodiversity was analyzed in several ways, but none returned conclusive results. The presence of the greatest number of target species in the deepest sinkhole (38 species at Rock Springs sinkhole 3 ) intuitively suggests a correlation, but 31 species were collected from Tincher Karst sinkhole 2 , which was 
Table 6. Spiders (continued) and pseudoscorpions occurring in HNF sinkholes.

\begin{tabular}{|c|c|c|c|c|c|c|c|c|c|c|c|c|c|c|c|c|c|c|c|c|c|c|c|c|c|c|c|c|c|c|}
\hline Site & $\begin{array}{l}\frac{0}{0} \\
\frac{0}{\pi} \\
\frac{\pi}{0} \\
\frac{0}{0} \\
\frac{0}{\pi} \\
\text { ஸ் }\end{array}$ & 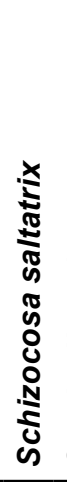 & 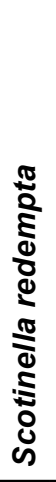 & 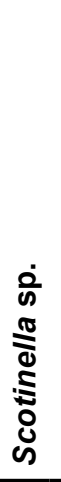 & 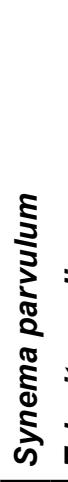 & 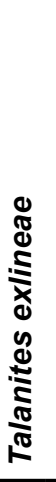 & 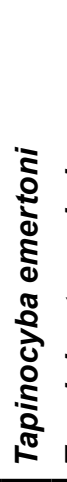 & 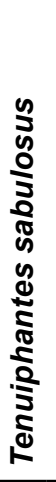 & 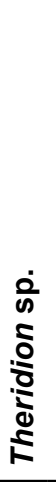 & 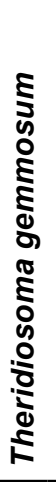 & 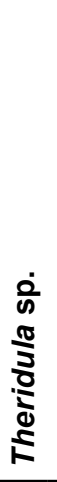 & 这. & 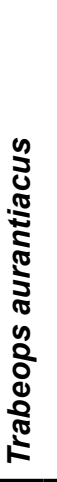 & 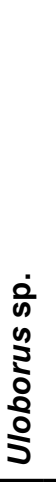 & 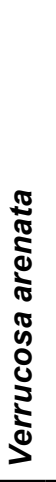 & 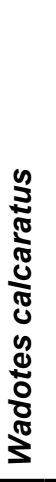 & 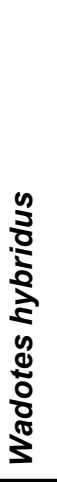 & 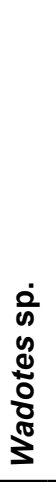 & 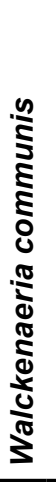 & 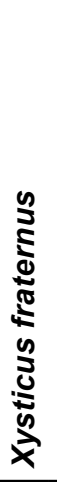 & 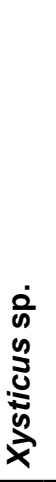 & 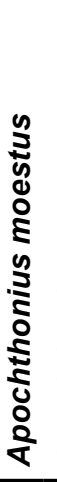 & 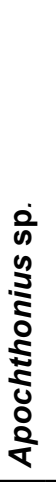 & 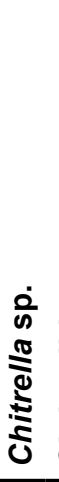 & $\begin{array}{l}0 \\
\frac{0}{0} \\
0 \\
\frac{\pi}{0} \\
\frac{0}{1} \\
0 \\
0 \\
\frac{1}{0} \\
0\end{array}$ & 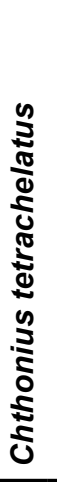 & 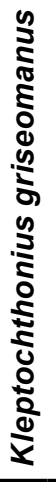 & 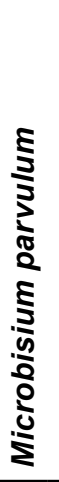 & $\begin{array}{l}\frac{0}{n} \\
5 \\
5 \\
\frac{5}{5} \\
0 \\
0 \\
\frac{0}{0} \\
\text { s }\end{array}$ & $\begin{array}{l}\frac{0}{0} \\
0 \\
\frac{\pi}{0} \\
\frac{0}{0} \\
: \frac{n}{0} \\
0 \\
0 \\
0\end{array}$ \\
\hline Bull Hollow sink 1 & & & $x$ & & & $x$ & & & & & $x$ & & & & & & & & & & & $x$ & & & & & & & & \\
\hline Bull Hollow sink 2 & & & $x$ & $x$ & & $\mathrm{x}$ & & & & & & & & & & $x$ & & & & $x$ & & & $\mathrm{x}$ & & & & & & $x$ & \\
\hline Boone Creek sink 1 & & $\mathrm{x}$ & $x$ & & & & & & & & & & & $x$ & & $x$ & & & & & & $x$ & & & & & & & & \\
\hline Boone Creek sink 2 & & & & & & & & $\mathrm{X}$ & & & & & & & & & & & & & & & & & & & & & & \\
\hline Mill Creek sink 1 & & & & & & & & & & & & & & & & & & & & & $x$ & & & & & & & & & \\
\hline Mill Creek sink 2 & & & & & & & & & & & & & & & & & & & & & & & & & & $x$ & & & & \\
\hline Deuchars North sink 1 & & $x$ & & & & $\mathrm{X}$ & & & & & & & & & & & & & & & & & & & & & & & & $x$ \\
\hline Deuchars South sink 1 & & & & & & & & $\mathrm{x}$ & & & & & & & & & & & & & & & & & & & & & & \\
\hline Deuchars South sink 2 & & & & & & & & $x$ & & & & & & & & & & & & & & & & & & & & & & \\
\hline \multicolumn{31}{|l|}{ Deuchars South sink 3} \\
\hline Rock Springs sink 1 & & & $x$ & & & & & $x$ & & & & & & & & $\mathrm{x}$ & & & & & & $x$ & $x$ & $\mathrm{X}$ & & & & & & \\
\hline Rock Springs sink 2 & & $x$ & & & & & $\mathrm{x}$ & $x$ & & & & & & & & & & & & & & $\mathrm{X}$ & & & & & & & & $x$ \\
\hline Rock Springs sink 3 & & & $x$ & & & & $x$ & $\mathrm{X}$ & $x$ & $x$ & & & & & $\mathrm{X}$ & $\mathrm{X}$ & & $x$ & & & & $\mathrm{X}$ & & & & & & $x$ & & \\
\hline Blanton sink 1 & & & & & & & & & & & $x$ & & & & & & & & & & & & & & & & & & & \\
\hline Blanton sink 2 & & & $x$ & & & & & & & & & & & & & & & & $x$ & & & & & & & & & & & \\
\hline Kimball sink 1 & & & $x$ & & & & & $\mathrm{X}$ & & $\mathrm{x}$ & $x$ & $\mathrm{x}$ & $x$ & & & & & $x$ & & & & $x$ & & & & & $\mathrm{X}$ & & & $x$ \\
\hline Kimball sink 2 & & & & & & & & $x$ & & $x$ & & $x$ & & & & & & & & & & $x$ & & & & & & & & \\
\hline Kimball sink 3 & & & & & $x$ & & & & & & & & & & & & & $x$ & & & & & & & & & & & & \\
\hline Kimball sink 4 & & & & & & & & & & & & & & & & & & $x$ & & & & $x$ & & & $x$ & & & & & \\
\hline Hager sink 1 & & & & & & & & & & & & & $x$ & & & & & & & & & & & & & & & & & \\
\hline Hager sink 2 & & & & & & & & $\mathrm{x}$ & & & & & & & & & & & & & & & & & & & & & & \\
\hline Tincher sink 1 & & & & $x$ & & & & $x$ & & $x$ & & & & & & & & & & & & & & & & & & & & $x$ \\
\hline Tincher sink 2 & & & $x$ & & & & & & & & & & & & & & $x$ & & & & & $x$ & $x$ & & & & & & & \\
\hline Union Cemetery sink 1 & & & $\mathrm{x}$ & & & & & $x$ & & & & $\mathrm{x}$ & & & & $x$ & & $x$ & & & & & & & & & & & & \\
\hline Union Cemetery sink 2 & & & & & & & & $x$ & & & & & & & & & & & & & & $\mathrm{x}$ & & $x$ & & & & & $x$ & \\
\hline $\begin{array}{l}\text { Deam Wilderness } \\
\text { sink } 1\end{array}$ & & & & & & & & & & & & & & & & & & & & & & $\mathrm{X}$ & & & & & & & & \\
\hline Bull Hollow control & $x$ & & & & & & & & & & & & & & & & & & & & & & & & & & & & & \\
\hline Tincher control & & & & & & & & & & & & & & & & & & & & & & & & & & & & & & \\
\hline $\begin{array}{l}\text { Deuchars North } \\
\text { control }\end{array}$ & & & & & & & & & & & & & & & & & & & & & & & & & & & & & & \\
\hline
\end{tabular}

one of the shallowest sampled at $0.4 \mathrm{~m}$ depth. The correlation coefficient of species diversity as a function of sinkhole depth was weak at 0.23 . Several other approaches to model sinkholes as cone or bowl-shaped depressions were analyzed to search for correlations with species diversity with similar results, until plant community subsets of the data were used. The strongest correlation was for sinks associated with glades, where a strong 0.98 correlation was found between modeled sink size and species richness, but a larger sample size is necessary to pursue this avenue of analysis further. 

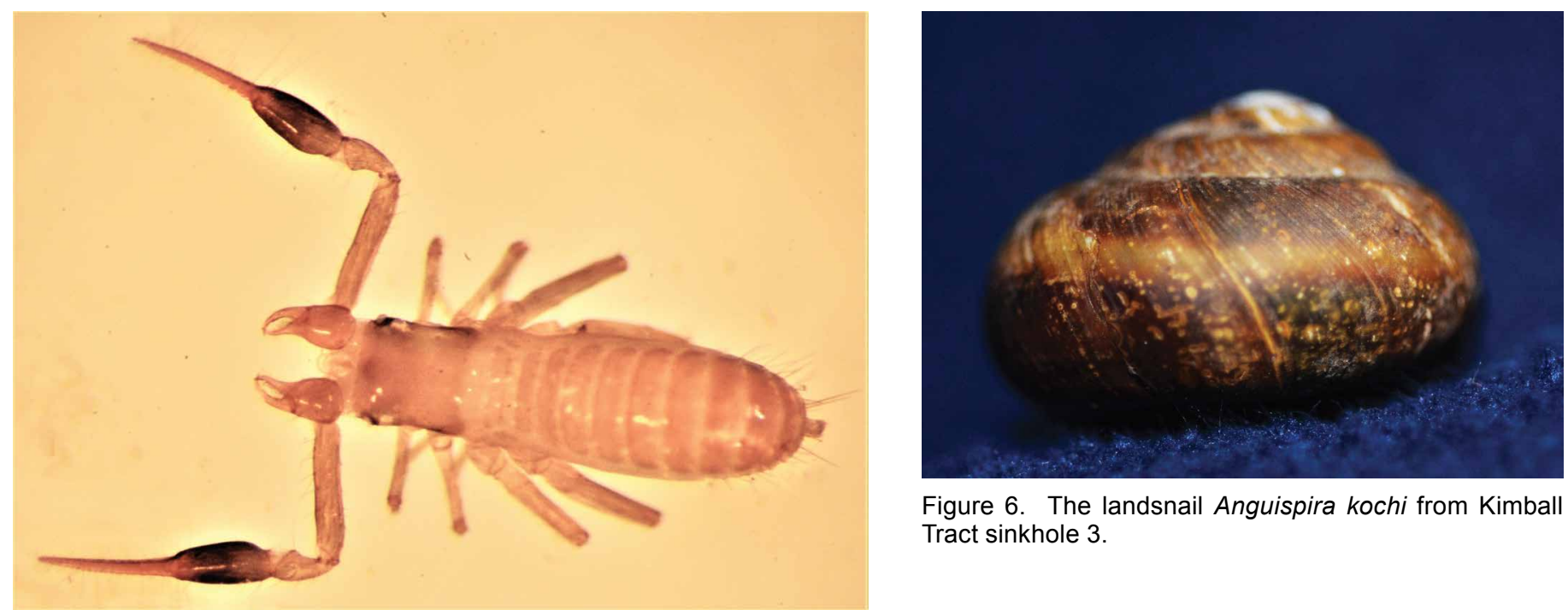

Figure 6. The landsnail Anguispira kochi from Kimball Tract sinkhole 3.

Figure 5. The pseudoscorpion Kleptochthonius griseoanus from Kimball Tract sinkhole 1.

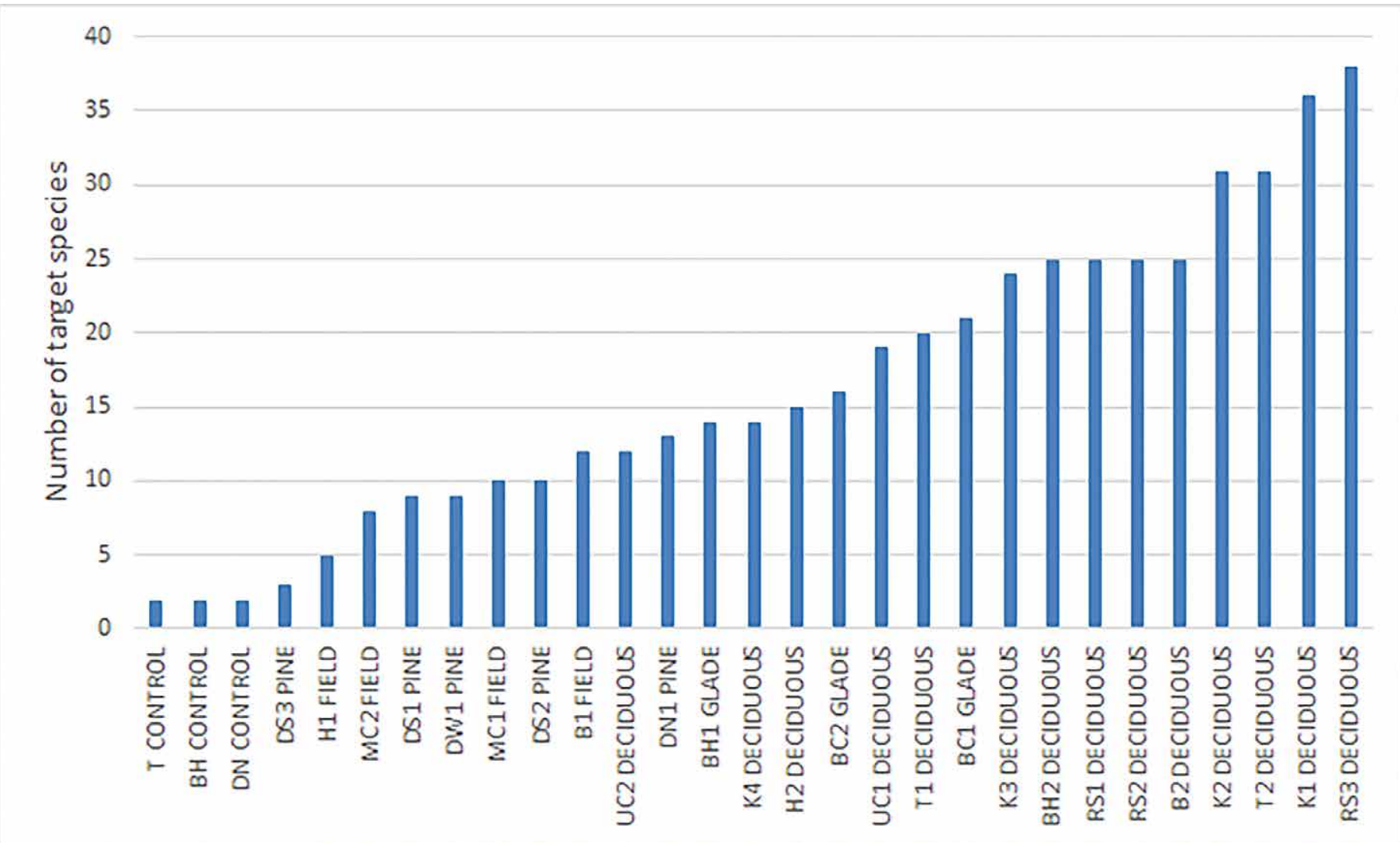

Figure 7. Histogram showing the number of target species sorted by surrounding plant community (sink designation abbreviations in Table 1).

The highest biodiversity in sinkholes resulted from the confluence of fauna from different contributing pools:

1. Widespread Eastern North America fauna - opportunistic species with wide ranges that are likely to occur in a variety of suitable habitats. These included terrestrial snails Carychium exile, Anguispira alternata, or Orchard Spider Leucauge venusta.

2. Southeastern fauna - warm latitude species on the northern edge of their ranges, using environmentally buffered habitats moderated against cold winter temperatures. These included the terrestrial snails Inflectarius ru- 


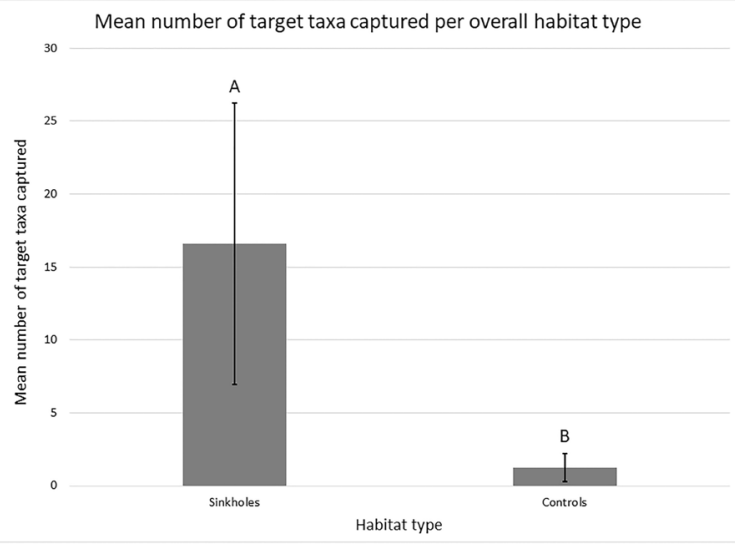

Figure 8. Mean species richness comparison between sinkhole habitats and controls, with different letters indicating significant differences at $p<0.05$.

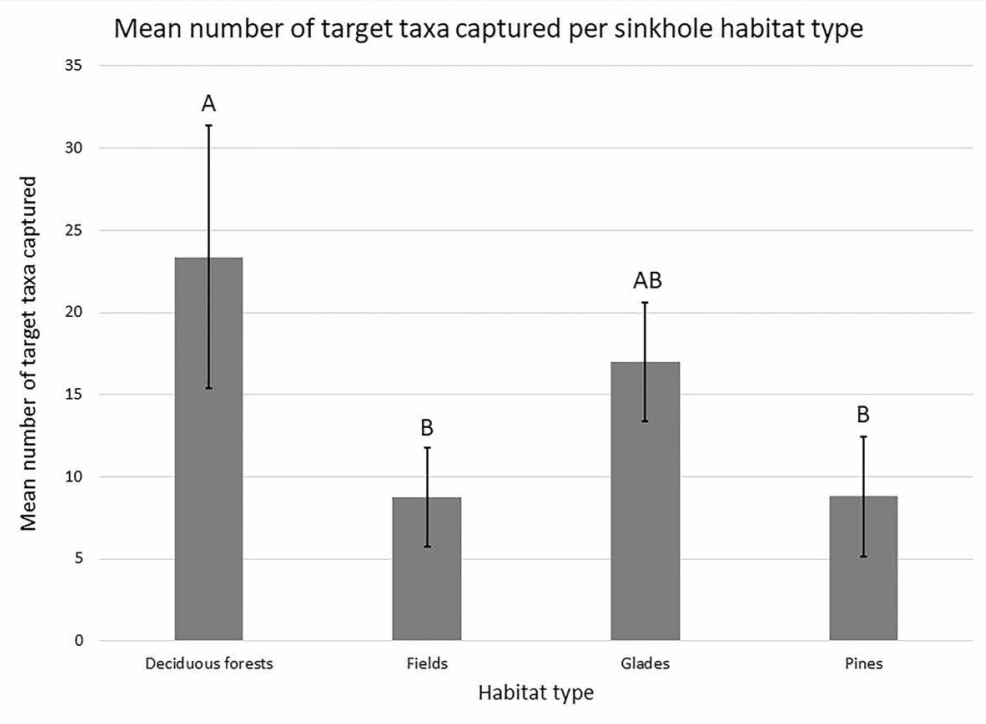

Figure 9. Mean species richness per sinkhole habitat type, with different letters indicating significant differences at $p<0.0005$.

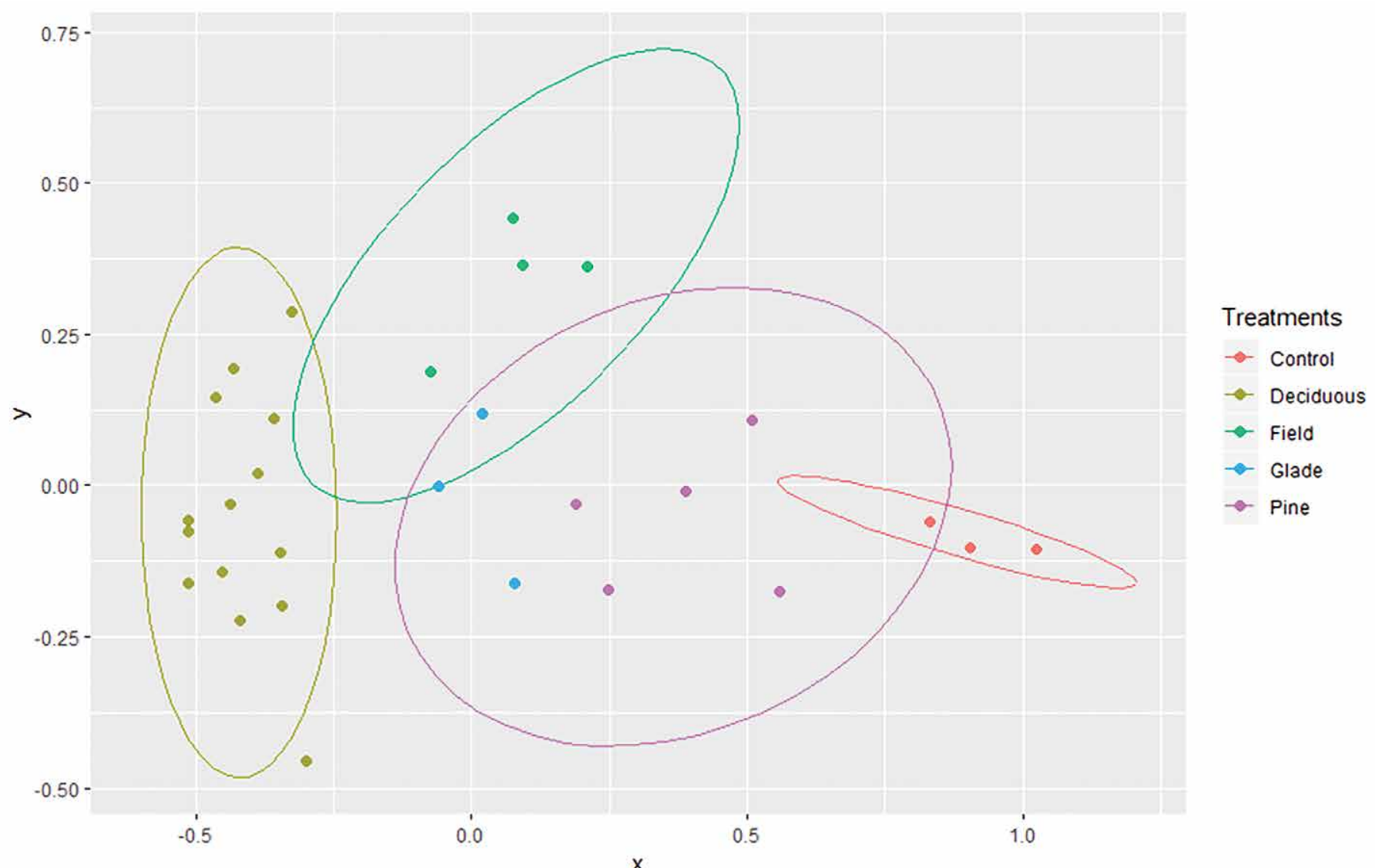

Figure 10. Plot of non-metric multidimensional scaling analysis comparing communities of target species within various habitats. Each dot represents such a community at a site. Ellipses represent $95 \%$ confidence intervals. The glade habitat lacked enough replicate sites to accurately predict a $95 \%$ confidence interval on this plot. This statistic produces an ordination based on a dissimilarity matrix without labelled axes.

geli, Mesomphix vulgatus, terrestrial isopods Ligidium elrodii, Miktoniscus medcofi, and spiders Anahita punctulata, Talanites exlineae.

3. Northern species - species adapted to inhabit cooler, northerly temperate latitudes, living in sinkholes and caves along the southern edge of their ranges, using environmentally-buffered habitats moderated against hot 
summer temperatures. Examples included the terrestrial snail Zonitoides limatulus, and spiders Cicurina arcuata, Cicurina itasca, Centromerus cornupalpis, and the millipede Scytonotus granulatus.

4. Endemic fauna - habitat-restricted species known only from southern Indiana or the somewhat broader karst region of the northern Interior Low Plateaus physiographic province (i.e., parts of Kentucky, southern Indiana, and adjacent southern Illinois). Southern Indiana species included the pseudoscorpion Kleptochthonius griseomanus, and millipede Conotyla bollmani; northern Interior Low Plateaus karst region species included the millipede Cleidogona unita. The pseudoscorpion Chitrella sp. falls into the latter category and is likely an undescribed species of particular interest; the two described species in this genus are obligate stygobionts.

5. Exotic species - opportunistic, cosmopolitan species introduced from Eurasia, e.g., terrestrial isopod Trachelipus rathkei, and the millipedes Oxidus gracilis and Ophyiulus pilosus.

\section{CONCLUSIONS}

The importance of biological studies of sinkholes was highlighted by the range expansion of eleven species of spiders, the range expansion of the millipede C. unita into Indiana, the finding of the pseudoscorpion $K$. griseomanus outside of a cave habitat, and the range expansion and potentially new species of the pseudoscorpion genus Chitrella. Evidence is provided for sinkhole floor communities being influenced by the plant communities present at their rims: unique sinkhole fauna assemblages were observed when sinkholes were clustered by their surrounding plant community (Fig. 5). The presence of deciduous forest had a positive impact on sinkhole fauna species richness and abundance (Figs. 2 and 4). Correspondingly, target fauna species richness and abundance declined in sinkholes where deciduous trees had been removed and replaced with fields or pine monocultures.

Of interest for conservation management of sinkholes, it is pertinent to point out that other research suggests a greater role of dissolved organic carbon percolating into caves from sinkholes lacking discrete openings, or via other portals into the epikarst (Gibert, 1986; Graening and Brown, 2003; Simon et al., 2007), with a de-emphasis on the importance of organic debris entering open sinkhole drains or cave entrances. The results of the HNF sinkhole project, along with that of other cited research, suggest that sinkholes are as important as cave entrances in terms of both ecological function and biological diversity in karst ecosystems.

\section{ACKNOWLEDGEMENTS}

This project was funded by the U.S. Forest Service, Hoosier National Forest, Bedford, Indiana. Our greatest thanks go to Steve Harriss, the Karst Coordinator for the HNF, who conceived of the project, facilitated its funding, suggested sites, and arranged for logistical support in a forest where some of the project sinks were many miles from the nearest road. Likewise, Ron Scott, the Lands and Minerals Program Manager for the HNF, provided field and logistical support. Charles Boswell kindly provided transportation to the remote Bull Creek sinkholes on Mogan Ridge. As always, the support of the HNF Forest Supervisor, Mike Chaveas, is appreciated in our work on the national forest. Field support was also provided by Keith Dunlap (Indiana Karst Conservancy), Salisa Lewis (Lewis and Associates), and Dr. Gavin Bradley (University of Louisville).

\section{REFERENCES}

Culver, D.C., and Pipan, T., 2009, The biology of caves and other subterranean habitats: Oxford, England, U.K., Oxford University Press, 256 p. Dourson, D.C., Langdon, K., and Dourson, J., 2013, Land snails of the Great Smoky Mountains National Park and southern Appalachians, Tennessee \& North Carolina: Bakersville, NC, USA, Goatslug Publications, 336 p.

Farlow, J.O. et al., 2001, The Pipe Creek sinkhole biota, a diverse late Tertiary continental fossil assemblage from Grant County, Indiana: The American Midland Naturalist, v. 145, p. 367-378. https://doi.org/10.1674/0003-0031(2001)145[0367:TPCSBA]2.0.CO;2.

Frushour, S.S., 2012, A guide to caves and karst of Indiana: Bloomington, IN, USA, Indiana University Press, 142 p.

Gibert, J., 1986, Ecologie d'un système karstique jurassien. Hydrogéologie, dérive animale, transits de matières, dynamique de population de Niphargus (Crustacé Amphipode): Mémoires de biospéologie, v. 13, p. 1-379.

Graening, G.O., and Brown, A.V., 2003, Ecosystem dynamics and pollution effects and pollution effects in an Ozark cave stream: Journal of the American Water Resources Association, v. 39, p. 1497-1505. https://doi.org/10.1111/j.1752-1688.2003.tb04434.x.

Hoffman, R.L., and Lewis, J.J., 1997, Pseudotremia conservata, a new cleidogonid milliped (Diplopoda: Chordeumatida), with a synopsis of the cavernicolous millipeds of Indiana: Myriapodologica, v. 4, p. 107-119.

Homoya, M.A., Abrell, D.B., Aldrich, J.R., and Post, T.W., 1985, The natural regions of Indiana: Proceedings of the Indiana Academy of Science, v. 94 , p. $245-268$.

Hubricht, L., 1985, The distributions of the native land mollusks of the Eastern United States: Fieldiana Zoology, p. 1-191. https://doi.org/10.5962/ bhl.title.3329.

Lewis, J.J., 2011, Conservation assessment of subterranean communities of the Hoosier National Forest: U.S. Forest Service, U.S. Department of Agriculture, $60 \mathrm{p}$.

Lewis, J.J., 2012, Subterranean ecosystems, in Whitaker, J.O., Jr. and Amlaner, C.J., Jr. eds., Habitats and Ecological Communities of Indiana: Presettlement to Present, Bloomington, IN, USA, Indiana University Press, p. 156-176.

Lewis, J.J., 1998a, The subterranean fauna of the Blue River area. Final Report. Volume 1.: Species at Risk Program, U.S. Geological Survey; The Nature Conservancy; Natural Heritage Program, Indiana DNR, Division of Nature Preserves, 241 p. 
Lewis, J.J., 1998b, The subterranean fauna of the Blue River area. Final Report. Volume 2.: Species at Risk Program, U.S. Geological Survey; The Nature Conservancy; Natural Heritage Program, Indiana DNR, Division of Nature Preserves, $60 \mathrm{p}$.

Lewis, J.J., Burns, R., and Lewis, S., 2004, The subterranean fauna of the Hoosier National Forest: U.S. Forest Service, U.S. Department of Agriculture, $190 \mathrm{p}$.

Lewis, J.J., Burns, R., and Rafail, S., 2002, The subterranean fauna of the Hoosier National Forest: U.S. Forest Service, U.S. Department of Agriculture, $115 \mathrm{p}$.

Lewis, J.J., and Lewis, S.L., 2012a, Subterranean fauna of the Hoosier National Forest: Patoka Lake and Lost River tracts: U.S. Forest Service, U.S. Department of Agriculture, $136 \mathrm{p}$.

Lewis, J.J., and Lewis, S.L., 2012b, The cave fauna of Indiana, in A guide to caves and karst of Indiana, Bloomington, IN, USA, Indiana University Press, p. 15-23.

Lewis, J.J., and Lewis, S.L., 2008, The subterranean fauna of the Hoosier National Forest. Final Report: U.S. Forest Service, U.S. Department of Agriculture, $186 \mathrm{p}$.

Lewis, J.J., and Lewis, S.L., 2009, The subterranean fauna of the Hoosier National Forest. Final Report: U.S. Forest Service, U.S. Department of Agriculture, $127 \mathrm{p}$.

Malcolm, D.R., and Chamberlin, J.C., 1960, The pseudoscorpion genus Chitrella (Chelonethida, Syarinidae): American Museum Novitates, p. $1-19$.

Milne, M.A., Foster, B., Lewis, J.J., Bishop, L., Hoffman, A., Ploss, T., and Deno, B., 2017, Spiders in Indiana: Seventy-one new and updated distribution records: Proceedings of the Indiana Academy of Science, v. 125, p. 75-85.

Muchmore, W.B., 2000, New species and records of Kleptochthonius from Indiana (Pseudoscorpionida, Chthoniidae): Journal of Arachnology, v. 28, p. 293-299. https://doi.org/10.1636/0161-8202(2000)028\%5b0293:NSAROK\%5d2.0.CO;2.

Muchmore, W.B., 1963, Redescription of some cavernicolous pseudoscorpions (Arachnida, Chelonethida) in the collection of the Museum of Comparative Zoology: Breviora, v. 188, p. 1-16.

Muchmore, W.B., 1973, The genus Chitrella in America (Pseudoscorpionida, Syarinidae): Journal of the New York Entomological Society, v. 81, p. 183-192.

Oksanen, J. et al., 2019, vegan: Community Ecology Package:, https://cran.r-project.org/package=vegan.

Pilsbry, H.A., 1948, Land mollusca of North America (north of Mexico). Volume II. Part 2: The Academy of Natural Sciences of Philadelphia Monographs, v. 3.

Powell, R.L., 1961, Caves of Indiana: Indiana Department of Conservation No. 8, 127 p.

Scott, W., 1910, The fauna of a solution pond: Proceedings of the Indiana Academy of Science, v. 20, p. 395-442.

Shear, W.A., 1971, The millipede family Conotylidae in North America with a description of the new family Adritylidae (Diplopoda: Chordeumida): Bulletin of the Museum of Comparative Zoology, v. 141, p. 55-98.

Sierwald, P., Draney, M.L., Prentice, T., Pascoe, F., Sandlin, N., Lehman, E.M., Medland, V., and Louderman, J., 2005, The spider species of the Great Lakes states: Proceedings of the Indiana Academy of Science, v. 114, p. 111-206.

Simon, K.S., Pipan, T., and Culver, D.C., 2007, A conceptual model of the flow and distribution of organic carbon in caves: Journal of Cave and Karst Studies, v. 69, p. 279-284.

White, H.W., 1930, The phytoplankton of a solution pond, with special reference to the periodicity of certain algae: Proceedings of the Indiana Academy of Science, v. 30, p. 123-140.

Wickham, H., Chang, W., Henry, L., Pedersen, T.L., Takahashi, K., Wilke, C., Woo, K., Yutani, H., and RStudio, 2019, ggplot2: Create elegant data visualisations using the grammar of graphics:, https://cran.r-project.org/package=ggplot2.

Woodall, C.W., Perez, J.A., and Thake, T.R., 2007, Forest resources of the Hoosier National Forest. Resource Bulletin NRS-18 2007: U.S. Forest Service, U.S. Department of Agriculture, 551 p. https://doi.org/10.2737/NRS-RB-18. 